\title{
The O-Ring Sector and the Foolproof Sector: An explanation for skill externalities
}

\author{
Garett Jones \\ George Mason University \\ August 2012 \\ [Forthcoming, Journal of Economic Behavior and Organization]
}

\begin{abstract}
Differences in worker skill cause modest differences in wages within a country, but are associated with massive differences in productivity across countries (Hanushek and Kimko, 2000). I build upon Kremer's (1993) O-ring theory of production to explain this stylized fact. I posit that there are two kinds of jobs: O-ring jobs where strategic complementarities to skill are large, and a diminishing-returns Foolproof sector, where two mediocre workers provide the same effective labor as one excellent worker. Both production functions are available to each country. In equilibrium, an econometrician would only see small returns to skill within a country. In a world where countries vary only slightly in the average skill of workers, these assumptions are sufficient to generate massive differences in cross-country income inequality while generating only small amounts of intra-country income inequality.
\end{abstract}

Corresponding Author: Garett Jones, Department of Economics and Center for Study of Public Choice, George Mason University. email: jonesgarett@gmail.com. The author would like to thank participants at the American Economic Association meetings, the Society for Economic Dynamics, and the GMU Public Choice Seminar for helpful comments. Remaining errors are my own. 
Why do skill differences that matter so little for individuals appear to matter so much for nations? In this paper, I offer one answer to this question: Because some jobs within each country involve strong skill complementarities, while other jobs within the same country do not. In equilibrium this is enough to generate small within-country returns to "skill" or "labor quality" or "IQ" while generating massive differences in productivity across countries.

In this framework, the average wage within a given country is pinned down by the productivity of the country's best workers in a Kremer-style "O-ring" sector, where output is potentially high quality but extremely fragile (1993). Kremer's example is the space shuttle Challenger, were the failure of the rubber O-rings on the booster rockets led to the shuttle's explosion. In the O-ring sector, high-skilled workers perform tasks that depend on strategic complementarities to skill. ${ }^{1}$

Other less-skilled workers in that same country aren't good enough to work in this increasing-returns O-ring sector-at least not without taking a massive fall in productivity and an accompanying massive cut in productivity. However, I consider the effect of the existence of another sector in the economy where output is produced using a conventional, diminishingreturns-to-labor "Foolproof" technology—essentially the Cobb-Douglas production function central to modern macroeconomics. In this sector, as in much empirical productivity accounting, all that matters is the average skill level of workers. I show that in general equilibrium, as long as there are no too many low-skilled workers (in a sense defined precisely below), these low-skill workers can be quite productive in this Foolproof sector, earning only slightly less than the highskilled workers in their own country.

\footnotetext{
${ }^{1}$ Charles Jones (2010) uses a Kremer-style complementarity channel along with a key role for intermediate goods to show how modest levels of resource misallocation (rather than lower levels of worker skill, as in Kremer) can reduce output substantially.
} 
Crucially, high-skilled workers can move between the O-ring and Foolproof sectors. The key assumption of this model is that the wage of high skilled workers must be equal across the two sectors, a simple invocation of the law of one price.

Under this model, within a given country, the less-skilled workers will earn only slightly less than the highly-skilled workers since in the Foolproof sector high- and low-skilled workers are close substitutes. This high substitutability is the assumption implicitly used whenever economists use "average years of schooling" in productivity accounting exercises, calibrations, or growth regressions. ${ }^{2}$

But across countries, a nation whose best workers are slightly lower in quality will be mисh less productive, since it means that workers in that nation's "O-ring" or "weak link" sector will produce much less. This model builds on the idea that there are two kinds of jobs within a given country: O-ring jobs that require a number of production steps where the product's value can be destroyed by one "weak link," (e.g., advanced manufacturing, high-level law or finance, factory farming), versus Foolproof jobs that can be done quite well either by isolated individuals or by a combination of workers with a variety of skill levels (e.g., many personal services, fast food preparation, routine law and banking matters, subsistence farming). While Kremer's model emphasizes the effects of static changes in the overall degree of strategic complementarity, the model here emphasizes the general equilibrium effects of differing levels of strategic complementarity across sectors. ${ }^{3}$

\footnotetext{
${ }^{2}$ Caselli (2005) engages in such a productivity accounting exercise, one that explicitly assumes that the micro-level return to human capital equals the aggregate return to human capital; he motivates this in part by noting the weak empirical evidence for education exernalities.

${ }^{3}$ Section I.4 of Kremer (2001) briefly explores multiple intra-country production functions that differ in their degree of strategic complementarity, and notes that high skill nations will employ more complicated (less Foolproof) technologies. The present paper demonstrates that if the alternative production function is Cobb-Douglas and aggregates labor according to growth accounting conventions a puzzle in development economics can be resolved, the puzzle of apparent skill externalities. The econometric implications discussed in II.D below make this potential resolution explicit.
} 
In general equilibrium the model generates results that match the data: Looking within a given country, the (modest) wage variance across workers can be driven entirely by differences within the Foolproof sector. But looking across countries, productivity variance will be driven by (large) differences across the O-ring sectors.

I noted above that the strongest version of this result holds only if there are not "too many" low-skilled workers. However, even if there are a large number of lower-skilled workers, I show below that they may still choose to use the relatively higher-wage Foolproof technology rather than the low-wage O-ring technology. The massive effects of skill on intra-country wages predicted by Kremer is reduced by the presence of an alternative production technology based on average worker skill.

But of course, all of this is for naught if the first sentence of this paper poses an invalid question. Is there evidence that skills and abilities matter little for individuals but a lot for nations?

Yes. For example, Hanushek and Kimko (2000) look at how national math and science scores predict long-run economic performance across countries; famously, East Asian economies combine high math and science scores with good economic performance. The authors show that average national math and science scores are excellent predictors of large differences in longterm economic performance even if they omit East Asian economies from their sample.

More importantly, they also show that such scores are weak predictors of how much typical immigrants from those countries earn when they arrive in the U.S.. Immigrants from high-scoring countries indeed earn more than immigrants from low-scoring countries, but the differences are quantitatively modest. Combining these two results, they conclude:

[T] he [cross-country] growth equation results are much larger than the corresponding results for individual earnings (Hanushek and Kimko, 2000, p. 1204). 
Further, they find that these test score measures, which they consider indices of "labor quality," are more important than typical years-of-schooling measures for predicting cross-country economic performance:

The growth model results...imply that the externalities must be significantly stronger for quality than for quantity. The estimated growth effect of one standard deviation of quality is larger than would be obtained from over nine years in average schooling (Hanushek and Kimko, 2000, p. 1204).

Jones and Schneider (2010) find much the same when they use cross-country differences in average IQ scores rather than Hanushek and Kimko's math and science tests. These IQ-based results, also discussed in Hanushek and Woessmann (2010), find that immigrants from highaverage-IQ countries indeed earn more upon arrival in the U.S.. But while one IQ point predicts only one percent more U.S. income for an individual worker (a result supported by a variety of micro-level labor econometric evidence, inter alia Zax and Rees (2002)), a country with an average IQ score one point higher would be predicted to produce six to seven percent more output per worker (Note that within a given country, one standard deviation in IQ is approximately 15 IQ points). The national IQ data used by Jones and Schneider have recently been used in the medical literature (Eppig et al., 2010) to argue that differences in infectious disease rates across countries may partially explain differences in average IQ across countries. Separately, Jones and Schneider (2006) also find that once one controls for national average IQ in cross-country growth regressions, the statistical significance of education quantity measures is diminished, thus supporting Hanushek and Kimko's second contention that quality of labor matters more than quantity of education. Thus, Jones and Schneider support both of 
Hanushek and Kimko's claims: test scores matter more for nations than for individuals, and test scores matter more than education at the cross-country level.

In the model below, I will focus on showing how modest differences in "labor quality" will generate small intra-country differences, but large inter-country differences. Whether one considers math and science scores or Lynn and Vanhanen's $(2002,2006)$ national average IQ scores as the preferred measure of labor quality is irrelevant to the model's interpretation. I will omit discussion of the quantity of education, since it does not appear to predict disproportionate cross-country income differences.

I begin by setting up a benchmark model with two production sectors and two levels of labor quality within a given country. In the model, I never appeal to exogenous cross-country productivity differences to explain cross-country income differences. I then discuss how regression results could be seriously misinterpreted if indeed workers do endogenously sort between production functions in the manner posited here. I follow with a discussion of some of the model's implications for productivity research, and conclude.

\section{The Benchmark Case}

A. Model

The O-ring production function is exactly that of Kremer (1993): Each firm combines an amount $k$ of capital with a group of $n$ workers to create output. Each worker performs her task accurately with a probability of $q$; if the worker makes an error (e.g., drops the vase) the output is worthless. An equivalent interpretation is that $q$ is the fraction of "potential value" that a particular worker actually creates, taking the quality of other workers as given.

To illustrate, I will omit capital and total factor productivity for the moment, and assume that workers all have the same skill level. In this simplified version, a firm's output equals $q^{n} n$. 
The immediate implication of this O-ring technology is that small declines in average skill lead to big declines in productivity. For example, if every production process has two activities, and the workers perform them perfectly, then $n=2, q=1$, and total output $=q^{*} q^{*} 2=2$. But if the same two-link process is used with two less-skilled workers of $\mathrm{q}=0.9$, then total output $=0.9^{2} * 2=1.62$; in this case a $10 \%$ drop in labor quality causes a $21 \%$ drop in output. And of course, if production in the O-ring sector involves many links, then even if worker quality only declines slightly, the productivity decline can be massive. Real-world examples noted by Kremer include the production of microchips and of high-end clothing; in the former case, a slightly-flawed product is literally worthless, while in the second case a slightly flawed product will sell for a steep discount at an outlet store.

Kremer shows that in equilibrium, workers within a given firm will only be combined with other workers of the same skill level-a fact that I make use of throughout this paper. Given the technology this is not only an equilibrium, it is also output maximizing. ${ }^{4}$ This endogenous sorting of workers is the source of the "strategic complementarity" contained within the Kremer model. In the model below, there will be a total of $\varphi$ firms in the O-ring sector. The number $\varphi$ will be determined by the free entry condition, which in the benchmark equilibrium will depend only on the supply of willing, high-skilled workers. Formally, output per firm, precisely following Kremer, is:

$$
\mathrm{Y}_{\mathrm{O} / \mathrm{\varphi}}=\mathrm{Bk}^{\alpha} \mathrm{q}^{\mathrm{n}} \mathrm{n}
$$

$\mathrm{Y}_{\mathrm{O} / \varphi}$ denotes O-ring sector output per firm. Here, $\mathrm{B}$ is an exogenous productivity factor identical across countries. In equilibrium, Kremer shows that the O-ring wage is simply a fraction (1- $\alpha)$ of per-firm output divided among the $n$ workers, an outcome comparable to the standard Cobb-

\footnotetext{
${ }^{4}$ A simple illustration, based on a four-worker economy, two of which are $\mathrm{q}=1$ and two $\mathrm{q}=0.5$ : Sorting on skill generates output of $1^{2} * 2+.5^{2} * 2=2.5$, while unsorted workers create $2 * .5 * 2=2$.
} 
Douglas result. All other returns accrue to owners of capital. A glance at (1) will remind the reader that if $n$ is large - if production chains are long, or if many different elements of the process must be done well to create substantial value-small differences in the quality of workers (q) can generate large differences in wages and output (cf. Acemoglu and Zilibotti (2001), who provide evidence that best-practice technologies demand the skilled workers abundant in OECD countries and scarce in many others).

Now we turn to the Foolproof sector, which uses a conventional Cobb-Douglas production function. Output in the Foolproof sector is similarly straightforward: It is a diminishing returns to scale sector where output depends only on average worker quality-one can think of personal services such as house cleaning, gardening and basic accounting. ${ }^{5}$ Subsistence farming would be another example relevant to less developed countries, while delicate high technology agriculture would employ O-ring technology. ${ }^{6}$ A key feature of the Foolproof sector is that workers of different skill levels can be linearly aggregated, something that cannot happen in the O-ring sector but which economists routinely do when using conventional Cobb-Douglas production functions (inter alia, Hendricks (2002)). In the economic growth literature, such an aggregation often goes under the label of "effective labor." This expression is often used to refer to the aggregate human capital of a population. As Nelson and Phelps (1966, p. 69) put it in an important early paper:

\footnotetext{
${ }^{5}$ Instead of modeling the Foolproof sector as using a diminishing-returns production technology, one could model it as constant returns to scale on the production side, with diminishing marginal utility on the consumption side when compared to O-ring output. Example: $\mathrm{U}=\mathrm{C}_{\mathrm{O}}+\mathrm{aC}_{\mathrm{F}}^{0.5}$. Alternately, O-ring output could be traded globally at constant prices, while Foolproof output could be a non-tradable consumer good, one that would quickly descend into diminishing marginal utility in the restricted domestic market. I model the diminishing returns on the production side for simplicity.

${ }^{6}$ Another complementary explananation for cross-country productivity differences in agriculture, set forth in Lagakos and Waugh (2010), is that workers face a subsistence food constraint. If workers within a country have comparative advantages in different sectors, but nations differ in productivity, workers with few skills in agriculture may be driven to work in agriculture if national productivity is low enough: They just need to eat, and if trade frictions are important, they must produce that food themselves. The model presented here complements that story because nations with low average skill levels will be less able to use fragile, highly productive O-ring agricultural technology, driving more workers toward the subsistence constraint and hence toward the agricultural sector.
} 
"[E]ffective labor"... is a weighted sum of the number of workers, the weight assigned to each worker being an increasing function of that worker's educational attainment. This specification assumes that highly educated men are perfect substitutes for less educated men...

This is the assumption used when modeling the Foolproof sector. High and low quality labor are "perfect substitutes" in the same sense that two hours of high quality labor are a "perfect substitute" for one hour of high quality labor: This is an assumption of linear isoquants, not an assumption that the slope of the isoquant equals unity. In the Foolproof sector, then, two mediocre gardeners can provide as much service as one excellent gardener-something quite untrue in the O-ring sector.

Note that this assumption of perfect substitutability is implicitly employed in growth regressions whenever "average years of schooling" is used as a human capital variable (inter alia, Benhabib and Speigel (1994)). Likewise, the U.S. Bureau of Labor Statistics makes the same assumption of perfect substitutability of different skill levels in its Multifactor Productivity Measurement program (Dean and Harper, 1998, p. 26 ff.).

There is a rich literature investigating the extent to which workers of different skill levels in fact are substitutes for each other. Hendricks (2002), for instance, finds evidence that the elasticity of substitution between skill levels may be five rather than infinity. The current paper contributes to that literature by spelling out a stark case: An economy that combines an O-ring sector where workers with different skills are never substitutes in equilibrium, with a Foolproof sector where they are perfect substitutes. This stark example makes it "too easy" to explain cross-country income differences, especially if production chains are long, so there is room for future work that lets the data speak on the question of the actual level of substitutability in different sectors. 
Under perfect substitutability, the aggregate effective labor force in the Foolproof sector, $\hat{L}_{\mathrm{F}}$, consists of the number of workers of each skill level multiplied by the skill of that set of workers, added up over all skill levels $S$. Mathematically,

$$
\hat{L}_{\mathrm{F}}=\sum^{S} q_{S} L_{S F}
$$

Workers with lower $q$ thus supply fewer units of effective labor. As noted above, in the Foolproof sector, output is subject to diminishing returns to scale, which may be taken to represent either technical limitations of expanding this sector or as a shorthand for diminishing marginal utility to the consumption of Foolproof goods. For simplicity, but without loss of generality, I assume that the labor share 1- $\alpha$ is the same across the two sectors, and I scale Foolproof productivity by $A$. The Foolproof sector uses capital as well (though this assumption is not critical); elasticity of output with respect to capital is $\beta$, with $1-\alpha+\beta<1$. Thus,

$$
\mathrm{Y}_{\mathrm{F}}=\mathrm{A}\left(\hat{L}_{\mathrm{F}}\right)^{1-\alpha} \mathrm{K}_{\mathrm{F}}^{\beta}
$$

(One could divide this production function by the population size in order to eliminate population scale effects, but since population is a fixed parameter, this would have no noticeable impact on the results below). Because the representative firm optimizes in the Foolproof sector, the marginal product of effective labor will equal the real wage, as usual. But note that workers with higher skill will supply more effective labor $\left(\mathrm{q}_{\mathrm{s}}\right)$, so they will earn a higher Foolproof sector wage $\left(\mathrm{w}_{\mathrm{SF}}\right)$ :

$$
\mathrm{w}_{\mathrm{SF}}=(1-\alpha) \mathrm{A}\left(\sum^{S} q_{S} L_{S F}\right)^{-\alpha} \mathrm{K}_{\mathrm{F}}{ }^{\beta} \mathrm{q}_{\mathrm{S}}=\delta \mathrm{Y}_{\mathrm{F}} / \delta \mathrm{L}_{\mathrm{SF}}
$$

Note that for the Foolproof sector, aggregate wages summed over all skill classes will equal the conventional (1- $\alpha)$ fraction of Foolproof output, because 


$$
\sum^{S}(1-\alpha) \mathrm{A}\left(\hat{L}_{\mathrm{F}}\right)^{-\alpha} \mathrm{K}_{\mathrm{F}}^{\beta} \mathrm{q}_{S} \mathrm{~L}_{\mathrm{SF}}=(1-\alpha) \mathrm{Y}_{\mathrm{F}} .
$$

I defer discussion of the capital market until the next subsection. Two more conditions remain to be spelled out. The first is the size of each class of workers. In the benchmark model, I assume only two types of workers: the high-skilled (h) and the unskilled (u). All high-skilled workers work either in the O-ring or the Foolproof sector: throughout, all labor, regardless of worker skill, is supplied inelastically. Therefore,

$$
\mathrm{L}_{\mathrm{h}}=\mathrm{L}_{\mathrm{hO}}+\mathrm{L}_{\mathrm{hF}}
$$

As noted above, in this benchmark model, I assume that there is only one other class of workers, the unskilled. They number $\mathrm{L}_{\mathrm{u}}$, and each has a skill level of $\mathrm{q}_{\mathrm{u}}$. Thus, the total inelastically supplied labor input equals $\mathrm{L}_{\mathrm{h}}+\mathrm{L}_{\mathrm{u}}$.

The final condition is the substitutability not of the labor inputs, but of the product outputs. For simplicity, I assume that these outputs are perfect substitutes, valued identically; this allows me to omit specifying consumer's utility functions, the relative price of O-ring versus Foolproof outputs, and other consumer-demand-side matters, and allows me to focus on the production side of general equilibrium.

\section{B. The role of capital}

The main concepts in this model concern the labor market in general equilibrium; however, for realism I also model the capital market. In the general case, capital is used in both the O-ring sector and the Foolproof sector. I first consider the O-ring sector. Here, capital is used optimally, with the marginal product of capital equaling the rental rate. For simplicity, I take the rental rate as given and identical across countries. The preferred interpretation of this assumption is to consider this the steady-state of a typical Ramsey or even Solow growth model. 
Alternatively, one can think of this as a model of a small open economy. Any of these assumptions pins down a unique marginal product of capital.

Note that since the O-ring function is a per-firm function, the marginal product of capital is determined via equation (1), not by summing over all firms; again, this follows Kremer (1993). Given the rental rate of capital $r$, Kremer shows that (1) yields an equilibrium capital stock of

$$
\left(\frac{\alpha q^{n} n B}{r}\right)^{\frac{1}{1-\alpha}}
$$

Since $q^{n}$ appears in both the equilibrium wage and the equilibrium capital expressions, this means that differences in worker skill across countries will have a multiplier effect through the capital stock. A modest rise in labor quality will attract substantially more capital.

In the Foolproof sector, the capital stock adjusts to equal the same real interest rate.

$$
\mathrm{r}=\beta \mathrm{A}\left(\hat{L}_{\mathrm{F}}\right)^{1-\alpha} \mathrm{K}_{\mathrm{F}}^{\beta-1}
$$

or equivalently

$$
\mathrm{r}=\beta \mathrm{A}\left(\mathrm{K}_{\mathrm{F}} / \hat{L}_{\mathrm{F}}\right)^{\alpha-1} \mathrm{~K}_{\mathrm{F}}^{\beta-\alpha}
$$

Because the Foolproof sector faces diminishing returns to scale, the production function implicitly has two free variables, scale $\left(\mathrm{K}_{\mathrm{F}}\right)$ and the capital-labor ratio $\left(\mathrm{K}_{\mathrm{F}} / \hat{L}_{\mathrm{F}}\right)$, that can adjust so that the marginal products of labor and capital equal the two prices (wages, determined in general equilibrium as seen below; and the interest rate, assumed exogenous). ${ }^{7}$ If the Foolproof sector instead faced constant returns to scale, then $\beta-\alpha$ would equal zero. In that case the interest rate would pin down a unique capital-labor ratio, which would in turn determine the equilibrium

\footnotetext{
${ }^{7}$ Since the Foolproof sector exhibits diminishing returns to scale, value will be left over after paying workers and capital their marginal products. I treat this is entrepreneurial profit, distributed lump-sum to either workers or suppliers of capital.
} 
wage: except in knife-edge cases, there would be no equilibrium where both O-ring and

Foolproof production functions were used under constant returns to scale.

\section{General Equilibrium}

The key general equilibrium condition is that if workers of the same skill level are

working in both the O-ring and the Foolproof sectors, then the wage across the two sectors must be equal. This is because workers are free to move across firms, so the law of one price must hold. In the benchmark case--which assumes only two skill levels and a relative abundance of high-skilled workers-the unskilled workers will only find employment in the Foolproof sector while high-skilled workers will work in both sectors. ${ }^{8}$ Formally, I state the key general equilibrium condition of wage equality across the two sectors:

$$
(1-\alpha) \mathrm{Bk}^{\alpha} \mathrm{q}_{\mathrm{h}}{ }^{\mathrm{n}}=\mathrm{w}_{\mathrm{hO}}=\mathrm{w}_{\mathrm{hF}}=(1-\alpha) \mathrm{A}\left(\hat{L}_{\mathrm{F}}\right)^{-\alpha} \mathrm{K}_{\mathrm{F}}{ }^{\beta} \mathrm{q}_{\mathrm{h}}
$$

Recall that the O-ring wage is predetermined by worker skill and the exogenous interest rate. In turn, the interest rate and the O-ring wage simultaneously and uniquely determine $\hat{L}_{\mathrm{F}}$, equilibrium Foolproof effective labor, and $\mathrm{K}_{\mathrm{F}}$, the equilibrium Foolproof capital stock. ${ }^{9}$

For ease of exposition, consider the case where the Foolproof sector does not use capital (so $\beta=0$ ), and all non-wage Foolproof income is given to consumers lump-sum as entrepreneurial profit. In this case, since all variables except $\hat{L}_{\mathrm{F}}$ are exogenous, it is straightforward to solve for $\hat{L}_{\mathrm{F}}$ :

\footnotetext{
${ }^{8}$ If only a few high-skilled workers existed, they would all work in the Foolproof sector: Because of the infinite marginal product of labor as labor inputs go to zero, the marginal product of Foolproof labor would necessarily be greater than the O-ring wage. I focus instead on the case where there are so many skilled workers that if they all worked in the Foolproof sector, their wage would be far below their O-ring wage: This ensures that skilled workers will use both production functions. In this case, the Foolproof sector is akin to a secondary labor market (Piore (1971), Cain (1976), Dickens and Lang (1985)), supplementary to the main O-ring labor market.

${ }^{9}$ The derivation of equilibrium capital and labor demand in a diminishing returns setting are conventional and omitted for brevity.
} 


$$
\hat{L}_{\mathrm{F}}=\left[(\mathrm{A} / \mathrm{B}) \mathrm{q}^{1-\mathrm{n}}\right]^{1 / \alpha}
$$

Thus, the equilibrium wage condition uniquely pins down the quality-weighted demand for labor in the Foolproof sector: The O-ring wage pins down the demand for Foolproof labor. Foolproof labor demand is rising in the relative productivity of the Foolproof sector and (since $q \leq 1)$ rising in the number of links in the O-ring chain.

Who then, exactly, will fill these Foolproof jobs? As long as there are not too many unskilled workers (in a sense defined precisely below), the answer is quite simple: All of the unskilled workers plus just enough skilled workers to push the Foolproof wage down to the level of the O-ring wage.

All labor is supplied inelastically, so everyone will work somewhere. And as long as (4) holds, every unskilled worker will work in the Foolproof sector, since Foolproof work offers a higher wage than the corresponding unskilled O-ring job.

In this section, as noted above, I refer to all workers who are below the highest skill level as "unskilled." I denote the quantity of such unskilled workers by $\mathrm{L}_{u}$; each worker has an identical skill level of $q_{u}$. This gives us only two classes of workers, $u$ and $h$. Equivalently, one can consider $\mathrm{L}_{\mathrm{u}}$ to be an undifferentiated mass of less-skilled workers with average skill level of $q_{u}$. That means that $\mathrm{L}_{u}$ workers will provide $\mathrm{q}_{\mathrm{u}} \mathrm{L}_{\mathrm{u}}$ units of effective labor. Once all of these unskilled workers are in the Foolproof sector, then at the margin, high-skilled workers are drawn over from the O-ring sector, each one slightly pushing down the Foolproof wage, until $\hat{L}_{\mathrm{F}}$ units of effective labor are supplied. I denote the number of high-skilled workers demanded by the Foolproof sector by $\mathrm{L}_{\mathrm{hF}}$. So $\mathrm{L}_{\mathrm{hF}}$ high-skilled workers are in the Foolproof sector (each providing $\mathrm{q}_{\mathrm{h}}$ units of effective labor), while the remaining $\mathrm{L}_{\mathrm{hO}}$ workers are in the O-ring sector.

Arithmetically, taking $\hat{L}_{\mathrm{F}}$ as in (5): 


$$
\mathrm{L}_{\mathrm{hF}}=\left(\hat{L}_{\mathrm{F}}-\mathrm{q}_{\mathrm{u}} \mathrm{L}_{\mathrm{u}}\right) / \mathrm{q}_{\mathrm{h}}
$$

Thus, while the high-skilled wage in both sectors is pinned down by the O-ring sector, the number of O-ring workers is pinned down by the demand for workers in the Foolproof sector. And Foolproof labor demand in turn is driven by the need to push the Foolproof wage down to the O-ring wage.

The key question, then, is whether this equilibrium will hold. It will indeed, as long as the aggregate of unskilled effective labor is weakly less than $\hat{L}_{\mathrm{F}}$. Informally, as long as there are at least a few high-skilled workers working in the Foolproof sector, the general equilibrium condition holds. In this benchmark case, I assume that this condition holds; below, I explore the alternative, which has potentially policy-relevant consequences.

Consider unskilled wages in the benchmark case, where $\mathrm{L}_{\mathrm{hF}}>0$. In this case $\mathrm{L}_{\mathrm{u}}$ workers earn an equilibrium wage of

$$
\mathrm{W}_{\mathrm{uF}}=(1-\alpha) \mathrm{A}\left(\hat{L}_{\mathrm{F}}\right)^{-\alpha} \mathrm{q}_{\mathrm{u}}(6)
$$

Comparing (4) (with $\beta=0$ ) to (6), one sees that in equilibrium, the ratio of high-skilled to unskilled wages is precisely $\mathrm{q}_{\mathrm{h}} / \mathrm{q}_{\mathrm{u}}$, a key result of the paper.

What is the size of the O-ring sector? As noted above, O-ring firms expand to meet the supply of high-skilled labor, $\mathrm{L}_{\mathrm{hO}}=\mathrm{L}_{\mathrm{h}}-\mathrm{L}_{\mathrm{hF}}$. The number of firms equals

$$
\varphi=\mathrm{L}_{\mathrm{hO}} / \mathrm{n}
$$

Since output is proportional to the number of firms, each of which produces according to (1), then $\mathrm{Y}_{\mathrm{O}}=\mathrm{Bk}^{\alpha} \mathrm{q}^{\mathrm{n}}(\mathrm{n} \varphi)$, and hence

$$
\mathrm{Y}_{\mathrm{O}}=\mathrm{Bk}^{\alpha} \mathrm{q}_{\mathrm{h}}{ }^{\mathrm{L}} \mathrm{L}_{\mathrm{hO}}
$$

Aggregate output equals $\mathrm{Y}_{\mathrm{O}}+\mathrm{Y}_{\mathrm{F}}$, and output per worker equals $\left(\mathrm{Y}_{\mathrm{O}}+\mathrm{Y}_{\mathrm{F}}\right) /\left(\mathrm{L}_{\mathrm{h}}+\mathrm{L}_{\mathrm{u}}\right)$. 
Note that while one could add in the representative agent's preferences across goods as part of the general equilibrium setup, this would be inconsequential, since I have already assumed for simplicity that the output of the two production functions are perfect substitutes trading 1:1, and each sector's output is already completely determined by the labor demand in the two sectors.

The qualitative comparative static results of the model (with a capital-free Foolproof sector) are summarized in Figures 1 and 2. Figure 1 illustrates that when worker skill is sufficiently low, the Foolproof sector will be the only appealing sector for workers. As the quality of workers increases, the only effect is that of diminishing returns, since an increase in worker quality is merely an increase in the quantity of Cobb-Douglas effective labor. When worker quality rises to $\mathrm{O}^{*}$, workers begin using O-ring technology, and a continued exogenous rise in the skill level of a nation's high-skilled workers will eventually draw all high-skilled workers into the O-ring sector.

Figure 2 illustrates that for a given skill gap between high-skilled and unskilled workers, the O-ring sectors are similar to rungs on a ladder, while the Foolproof sector captures the gaps between the rungs. If most modern, developed-country output is indeed produced using fragile O-ring production functions, this implies that the return to finding some Foolproof-style production technology is very high indeed: The less-skilled workers would gladly work as Foolproof substitutes for high-skilled workers rather than take the massive pay cut caused by the O-ring production technology. 


\section{Discussion and Extension of the benchmark model}

\section{A. General Discussion}

Why doesn't the promise of high productivity lure unskilled workers away from the relatively disappointing Foolproof sector? The answer flows directly from (1), Kremer's O-ring production function. Consider a case where $\mathrm{q}_{\mathrm{h}}=1$ and $\mathrm{q}_{\mathrm{u}}=0.9$. As noted above, if there are only two links in the O-ring production chain, and even if I ignore the multiplier effect of capital, two unskilled workers will produce only $0.9^{2}=81 \%$ as much as two high-quality workers. In the Foolproof sector by contrast, an unskilled worker will produce $90 \%$ as much as a skilled worker, and will earn $90 \%$ of the wage of skilled worker (by equation 6)-so of course she will stay in the Foolproof sector.

When we look across countries with different skill levels, though, what will we see? In a country whose best workers have $\mathrm{q}_{\mathrm{h}}=0.9$, output in the 2-link O-ring sector will (continuing to ignore capital) produce $0.9^{2}=81 \%$ as much as in the $\mathrm{q}_{\mathrm{h}}=1$ economy. But in the $\mathrm{q}_{\mathrm{h}}=0.9$ economy, many more workers will work in the Foolproof sector.

Why? First, because in the $\mathrm{q}_{\mathrm{h}}=0.9$ economy, the O-ring wage is lower than in the $\mathrm{q}_{\mathrm{h}}=1$ economy, so it takes many more Foolproof workers to push the wage down to the lower O-ring level. Second, because the $\mathrm{q}_{\mathrm{h}}=0.9$ workers produce only nine-tenths of the effective labor of workers in the $\mathrm{q}_{\mathrm{h}}=1$ economy; therefore, it takes $10 \%$ more workers to have the same percentage impact on wages in the Foolproof sector.

This result occurs because the two total factor productivity parameters-A and B in the model-are identical across countries. Thus, the very assumption of identical cross-country TFP that is such a barrier to explaining cross-country income differences in most models actually helps to explain cross-country income differences in the O-Ring/Foolproof model. 


\section{B. Unskilled workers out of reach of the O-ring.}

What happens if there are so many unskilled workers in the economy that equation (4) is violated? What if the Foolproof wage falls below the O-Ring wage? Figure 3, a labor demand curve, illustrates such a situation by considering the effect of different levels of unskilled workers on the equilibrium unskilled wage. Note that the key assumption of the model, mentioned in the first page of this paper, is that skilled workers move freely and voluntarily between the two sectors, pinning down an identical skilled wage in both sectors. But if unskilled labor $\left(\mathrm{L}_{\mathrm{u}}\right)$ becomes so massive that (assuming $\beta=0$ )

$$
(1-\alpha) B k^{\alpha} q_{h}{ }^{n}>(1-\alpha) A\left(q_{u} L_{u}\right)^{-\alpha} q_{h}
$$

then we are in a new world. If there are only a few too many unskilled workers, then all unskilled workers will work in the Foolproof sector. In this case, unskilled wages fall, the ratio of wages between skilled and unskilled workers will be greater than $\mathrm{q}_{\mathrm{h}} / \mathrm{q}_{\mathrm{u}}$, and the more unskilled workers there are, the greater this ratio will be. Socially, there will now be a noticeable difference between the high-skilled and unskilled workers, since they will work in completely different sectors of the economy, with the high-skilled working only in O-ring jobs and the unskilled working only in Foolproof jobs; it will be a "Two Nations" (Hacker, 2003) economy.

\section{Unskilled workers pushed to the next rung down the ladder.}

But if the number of unskilled workers is vast compared to the Foolproof demand, then something both different and familiar will occur: Unskilled workers will be pushed down to the next "rung" of the O-ring ladder, as illustrated metaphorically in Figure 2 and in labor demand form in Figure 3. The benchmark model's equilibrium condition (4) will hold for unskilled workers rather than for skilled workers. 
The only way that unskilled workers will prefer to work in the O-ring sector is if there are so many unskilled workers that they alone create so much labor supply that the equilibrium skilled wage is pushed far below the skilled O-ring wage. To reuse the simple capital-free example from section IIA, assuming $\mathrm{q}_{\mathrm{U}}=0.9 \mathrm{q}_{\mathrm{H}}$ and a two-link production chain, then if the supply of unskilled labor is so large that the unskilled wage falls dramatically, then the unskilled workers will be drawn into the O-ring sector, working at $81 \%$ of the skilled wage. Again, in the $\beta=0$ case,

$$
(1-\alpha) B^{\alpha}{ }^{\alpha}{ }_{u}{ }^{n}=(1-\alpha) A\left(q_{u} L_{u}\right)^{-\alpha} q_{u}
$$

In this case, the unskilled workers would be in the same position as the skilled workers in the benchmark model: They would freely move between the two sectors in order to keep the wage in equilibrium.

In principle, this could lead to discontinuities in the use of the two production functions as the number of unskilled workers changes: If there are only a few unskilled laborers in an economy, these workers would all work in the simple Foolproof sector along with a few skilled workers; if there are a moderate amount of unskilled workers, they would work in a "Two Nations" condition, earning wages well below that of their skilled counterparts. But if there were a vast numbers of unskilled workers, some of them would work in a familiar O-ring sector one rung down the economic ladder. Thus, this image of Figure 2: The O-ring sectors as rungs on an economic ladder, with the Foolproof sector as the spaces between the rungs.

In Kremer's original model, the rungs on the ladder were the only places for workers to reside, so small differences in skill would necessarily cause large differences in wages and aggregate output within a given country. But this is not what we typically see in wage regressions: Instead, as noted in the introduction, worker skills like math scores and IQ have only 
modest impacts on individual wages. But in the O-Ring/Foolproof model, the vacuum between the rungs on the ladder is filled by a routine diminishing returns sector, where small differences in skill indeed lead to small differences in wages and productivity, just as we typically see in the data.

\section{Econometric implications.}

Two key empirical results the flow from the benchmark model:

1. When a labor econometrician estimates Mincer-style (1974) wage regressions within a given country whose data are generated by the benchmark model (i.e., one with a relatively high ratio of skilled to unskilled labor), she will find that the wage is precisely proportional to $q$, the skill of the worker. This is because the only variation in wages she will find will be across workers in the Foolproof sector, a sector that behaves in a conventional, diminishing returns manner.

2. But when a macroeconometrician estimates cross-country productivity regressions across countries whose data are generated by this model, she will find a completely different result: Productivity differences for countries with different levels of $\mathrm{q}_{\mathrm{H}}$ will be vast. This is because across countries, nations with different average skills will generally be on different rungs of the O-ring ladder, generating large productivity differences, with only a few lightlypopulated low-skill countries using the Foolproof production function, perhaps in the form of resource extraction and subsistence agriculture.

\section{Conclusion}

This paper builds on an insight latent within Kremer's (1993) O-ring theory of economic development: Within a given country, when two groups of O-ring workers differ in their skill by 
a factor of $\varepsilon$, their equilibrium wages will differ by a factor on the order of $n \varepsilon$, where $n$ is the number of links in the O-ring production chain. That means that if any other production process is available within the country that would create a pay gap of less than $n \varepsilon$, that alternative production process could readily hire the slightly-less-skilled workers. Thus, slightly-less-skilled workers would leave the O-ring sector and move to the alternative sector. Since such labor mobility is easy within countries but difficult across countries, an econometrician will readily find evidence of large returns to skill across countries but small returns to skill within countries.

In this paper, I've used a conventional diminishing returns to labor sector as one example of a non-O-ring sector, but other production processes would surely generate the same outcome. Any production function that fills the space between the "ne gaps" or the "rungs on the O-ring ladder" would do the job. If there is more than one kind of job-and surely there is-then this model may prove useful in explaining how differences in "labor quality" (Hanushek and Kimko, 2002) can matter very little for individuals while still mattering massively for entire nations. 
Figure 1

Skill Differences, Productivity, and Endogenous Sorting between Technologies
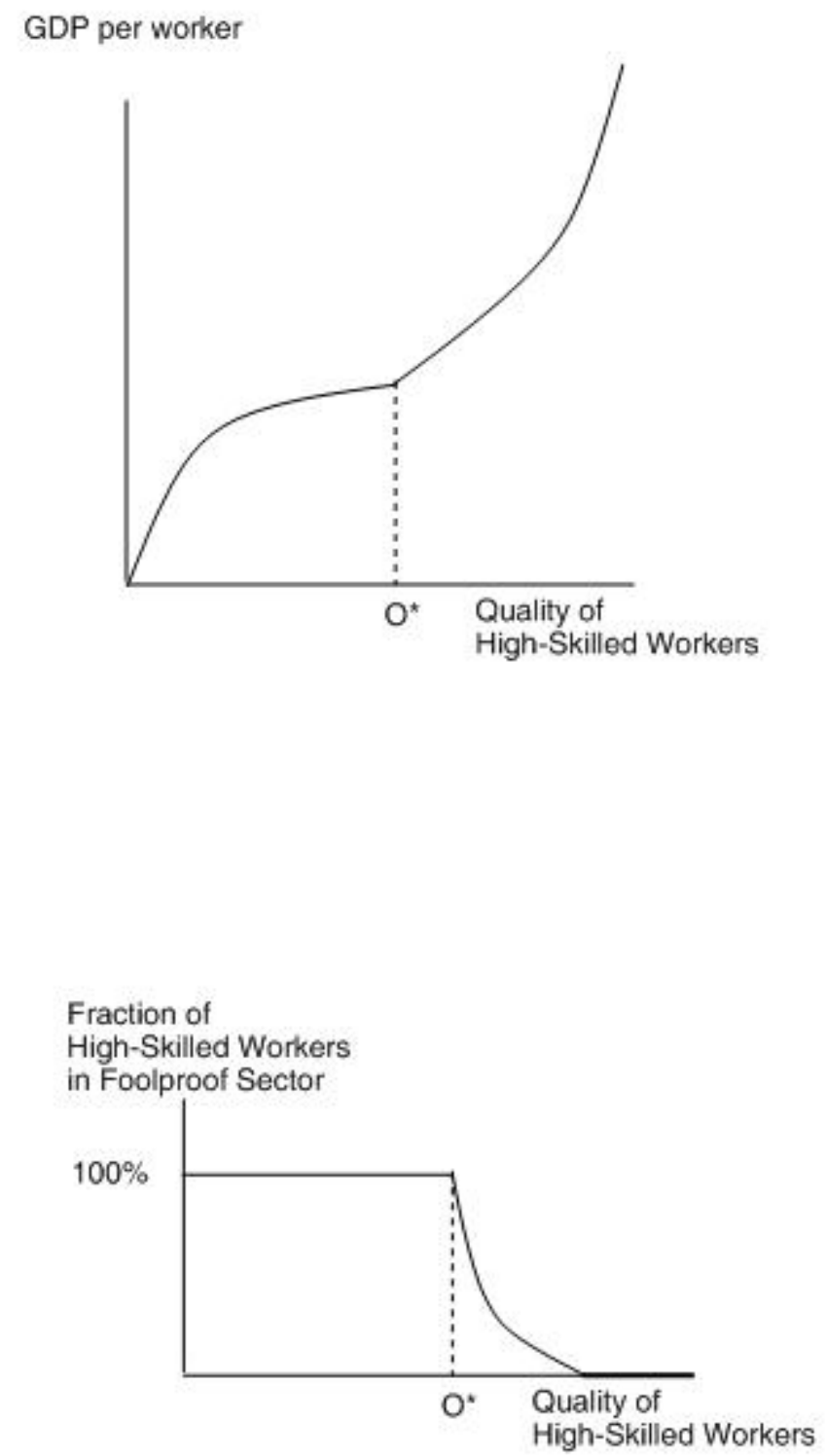

The figures above depict the equilibrium effect of an exogenous change in the skill level of high-skilled workers on GDP per capita (above) and on the share of workers using the Foolproof technology (below). $\mathrm{O}^{*}$ is the endogenously determined skill level above which high-skilled workers start shifting into the O-Ring technology.

Above: The Foolproof technology has diminishing returns to skill, while the O-Ring technology has increasing returns to skill. Below: As the skill level of the best workers rises, at some skill level $\mathrm{O}^{*}$ workers begin to be absorbed by the O-Ring sector. Eventually, all high-skilled workers are in the O-Ring sector. These qualitative results hold whether or not there are a mass of unskilled workers in the same economy. 
Figure 2

The Ladder: O-Ring Sectors as rungs, Foolproof Sectors as gaps between rungs

Gap between the rungs:

Filled by Foolproof sector as long as only a few unskilled workers are in labor market.

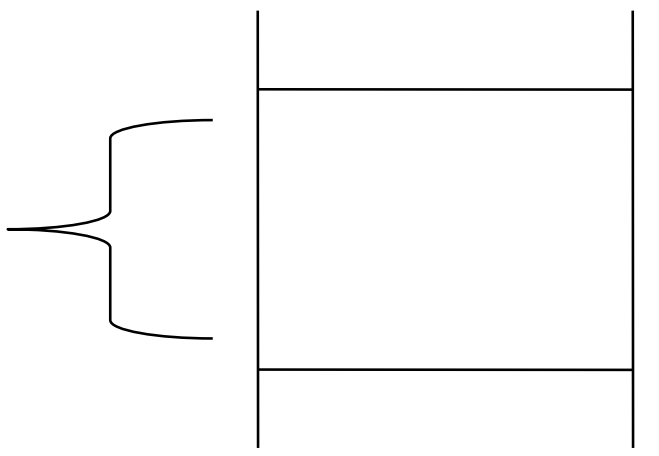

O-Ring Sector:

High-skilled

Potential O-Ring Sector:

For unskilled workers, if there are enough unskilled. 
Figure 3

Effect of an increase in the quantity of unskilled workers on unskilled wages

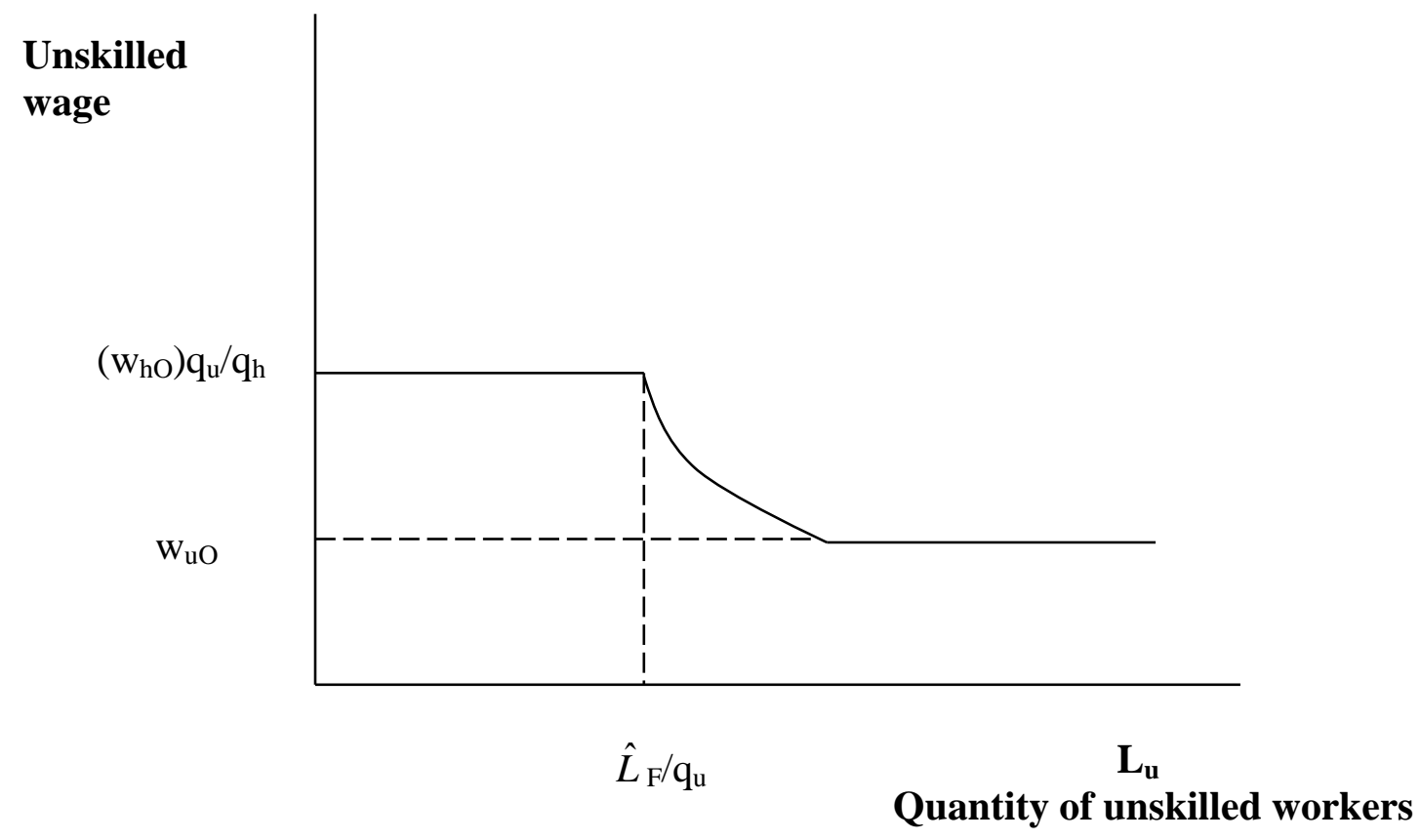

Notes: Solid line denotes demand for unskilled labor. Vertical dash denotes level of unskilled labor below which at least some high skilled workers are in the Foolproof sector; effective Foolproof labor demand, $\hat{L}_{\mathrm{F}}$, defined in (5). Curved solid line denotes range where all unskilled are in Foolproof sector and more workers push down wages. Horizontal dashed line denotes wage corresponding to lower O-ring rung in Figure 2. 


\section{References}

Acemoglu D, Zilibotti F 2001. Productivity Differences Quarterly Journal of Economics 116, 563-606.

Benhabib J, Spiegel M 1994 The Role of Human Capital in Economic Development: Evidence from Cross-Country Data Journal of Monetary Economics 34:143-173.

Cain GG 1976 The Challenge of Segmented Labor Market Theories to Orthodox Theory: A Survey Journal of Economic Literature 14: 1215-1257.

Caselli F 2005 Accounting for Cross-Country Income Differences in P. Aghion and S. Durlauf, Handbook of Economic Growth, North-Holland.

Dean E, Harper M 1998 The BLS Productivity Measurement Program Conference on Research in Income and Wealth conference on New Directions in Productivity Analysis, Bureau of Labor Statistics.

Dickens W, Lang K 1985 A Test of Dual Labor Market Theory American Economic Review 75:792-805.

Eppig C, Fincher CL, Thornhill R 2010 Parasite prevalence and the worldwide distribution of cognitive ability Proceedings of the Royal Society B, June.

Hacker A 2003 Two Nations: Black and White, Separate, Hostile and Unequal (Scribner's, New York).

Hanushek E, Kimko D 2000 Schooling, Labor-Force Quality, and the Growth of Nations American Economic Review 90:1184-1208.

Hanushek E, Woessmann L 2010 The Economics of International Differences in Educational Achievement," NBER Working Paper.

Hendricks L 2002 How Important is Human Capital for Economic Development? Evidence from Immigrant Earnings American Economic Review 92:198-219.

Jones C 2007 Intermediate Goods, Weak Links, and Superstars: A Theory of Economic Development, working paper, University of California, Berkeley.

Jones G, Schneider WJ 2006 Intelligence, Education, and Economic Growth: A Bayesian Averaging of Classical Estimates (BACE) Approach Journal of Economic Growth, vol. 11(1), pages 71-93.

Jones G, Schneider WJ 2010. IQ in the Production Function: Evidence from Immigrant Earnings Economic Inquiry vol. 48(3), pages 743-755. 
Kremer M 1993 The O-Ring Theory of Economic Development Quarterly Journal of Economics, vol. 108(3), pages 551-75.

Lagakos D, Waugh ME. Specialization, Agriculture, and Cross-Country Productivity Differences Working paper Arizona State University.

Lynn R, Vanhanen T 2002 IQ and the Wealth of Nations. Westport, CT: Praeger Publishers.

Lynn R, Vanhanen T 2006 IQ and Global Inequality. Augusta, GA: Washington Summit Publishers.

Mincer J 1974 Progress in Human Capital Analyses of the Distribution of Earnings Working Paper \#53, National Bureau of Economic Research.

Nelson RR, Phelps ES 1966 Investment in Humans, Technological Diffusion, and Economic Growth American Economic Review, v 56(1) pps. 69-75.

Piore MJ 1971 The dual labor market: theory and implication. in DM Gordon, ed.,1971, Problems in Political Economy: an urban perspective. Lexington, MA: Heath Publishers.

Zax JS, Rees DI 2002 IQ, Academic Performance, Environment, and Earnings Review of Economics and Statistics, 84, 4, 600-616. 